\title{
The challenges experienced by small-scale fishing communities of Lake Kariba, Zimbabwe
}

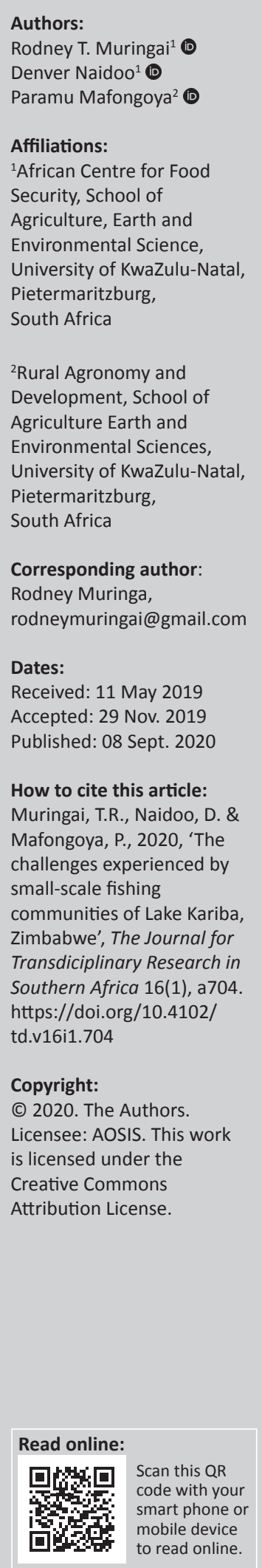

Small-scale fisheries play a significant role in enhancing livelihoods, creating employment and contributing to food security especially in developing countries. Rural fishing communities are highly dependent on natural resources, which are climate sensitive. Many research efforts have been made to understand the impacts of climate change on fisheries and fishing economies. However, little attention has been given to understand the challenges experienced by small-scale fishing communities in developing countries in Africa. This article assesses non-climate change and climate change-induced challenges according to the experiences of the gillnet small-scale fishers of Sanyathi fishing basin of Lake Kariba, Zimbabwe. The study used a qualitative research design, and data were collected using semi-structured in-depth interviews with fishers. Thematic content analysis was used to analyse interview transcripts. The study results showed that declining fish catches is one of the major challenges experienced by fishers. The main themes that emanated as the challenges faced by fishers are food insecurity, wildlife attacks, lack of access to information systems, lack of fishing equipment, the existence of the predator crayfish, poor lake co-management and shrinking fishing boundaries. Overall, the study found that fish production is negatively affected by several political, economic and environmental factors; therefore, development through the public and private organisations should incorporate small-scale fishers in policy formulation to positively enhance livelihoods and food security.

Keywords: climate change; small-scale fisheries; wildlife; food insecurity; fish production.

\section{Introduction and study background}

Small-scale fisheries (SSFs) and the associated post-harvest activities significantly contribute to food security and support millions of livelihoods worldwide. Small-scale fisheries account for more than $90 \%$ of the world's capture fishers and provide livelihoods and food security for millions of individuals around the globe (Basurto et al. 2017; Frawley, Finkbeiner \& Crowder 2019). Globally, more than 1 billion people derive their protein and micronutrients from fish, whilst in sub-Saharan Africa it is the main or only source of protein to more than $20 \%$ of the population (Mohammed \& Uraguchi 2013). According to the World Bank (2013), SSFs and aquaculture produce contribute about $10 \%$ of total agricultural exports, and the value of fish trade surpasses the value of trade of all other animals combined.

According to Tietze (2016) and Frawley et al. (2019), SSFs are characterised by labour-intensive harvesting strategies, relatively small fishing vessels, short fishing trips, close to shore, low relative catch per vessel and limited capital investment. Therefore, small-scale fishing communities are amongst the most destitute socio-economic groups in developing countries. Small-scale fisheries are exposed to a range of natural and anthropogenic stressors, such as climate change, resource scarcity, poor socio-economic conditions and policy that require changes in their behaviour to mitigate damages and to take advantage of opportunities (Gammage, Jarre \& Mather 2017). The impacts of climate change such as rising global average temperature and changes in precipitation patterns are already affecting ecosystems, biodiversity and human systems throughout the world (Kotir 2011). Climate change is increasingly threatening the fishing industry, that is, the ability of fisheries to sustain livelihoods, contribute to economic growth and improve food security (Rockefeller-Foundation 2014). According to Barange et al. (2018), loss of production and infrastructure arising from the increased occurrence of extreme weather events such as floods, cyclones and droughts are some of the short-term climate change impacts on SSFs.

Declining fish catches of SSFs negatively affect the living conditions of the fishing communities (Blythe Murray \& Flaherty 2014). Multiple natural and human factors can be attributed to declining fish catches of SSFs. Cawthorn (2011) and Benkenstein (2013) argue that declining fish 
catches cannot be solely attributed to climate change, but can also be a result of social vegetative issues in lakes and pollution, overfishing and illegal fishing. Research has been conducted to understand the impacts of climate change on fish productivity and the vulnerability of SSFs to climate change. However, little is known about the challenges experienced by SSFs of Lake Kariba in Zimbabwe. Therefore, this study sought to answer the following research question: what are the climatic and non-climatic challenges experienced by small-scale gillnet fishers in Sanyathi fishing basin of Lake Kariba in Zimbabwe?

\section{Significance of the study}

The Food and Agriculture Organisation (FAO) states that Zimbabwe has over $3910 \mathrm{~km}^{2}$ of inland water bodies that support small-scale and commercial fisheries (FAO 2019). Lake Kariba is the predominant water body that supports both commercial and SSFs that contribute significantly to the economies of Zimbabwe and Zambia (Ndhlovu et al. 2017). Small-scale fisheries in Lake Kariba contribute to providing employment as well as food security to the local people in Kariba. However, according to FAO (2019), Lake Kariba is characterised by declining fish production. Therefore, it is essential to understand what the SSFs perceive to be the challenges hindering fish production. This study will show the underlying challenges experienced by SSFs, which will provide helpful information for the development and the enactment of useful types of corresponding interventions from governments, policymakers, non-governmental organisations (NGOs), development agencies and interested stakeholders.

\section{Research methodology}

This study was conducted in Sanyathi fishing basin on the shores of Lake Kariba in Zimbabwe. Lake Kariba is approximately $365 \mathrm{~km}$ from the capital city of Harare and it borders Zimbabwe and Zambia in the north-western part of Zimbabwe. Lake Kariba is the second largest man-made lake in the world by water holding capacity (Ndhlovu et al. 2017). Sanyathi fishing basin lies within a wildlife-protected area; hence, humans and wild animals share the space and resources. The study area was selected mainly because of its contribution of fish supplies to small-scale fishing communities in Mashonaland West province.

\section{Data collection}

This study adopted an integrated research design. An integrated research design incorporates both qualitative and quantitative data to answer the research question. Primary data were mainly used in this study. Semi-structured questionnaires, in-depth interviews and focus group discussions (FGDs) were used to gather information from the SSFs. A purposive sampling technique was used to select study participants. Sixty-six semi-structured questionnaires were administered to heads of small-scale fishing households. The questionnaire was used to collect quantitative data about the socio-economic demographic information. In addition, three FGDs were conducted in three different communities under Sanyathi fishing basin: Gache-gache, Nyaodza and Fothergil. The FGDs were made up of both men and women, ordinary fishermen, community leaders and fisheries extension officers from Lake Kariba Fisheries Research Institute (LKFRI). Focus group discussion questions were designed to identify climate-induced and non-climate-related challenges that affect fishing practices of SSFs in their respective fishing zones. Observation data collecting tool was also used whereby the researcher paid attention to access and availability of basic services to the fishing communities, infrastructural developments and fishing materials used by the SSFs.

\section{Data analysis}

Quantitative data obtained from semi-structured questionnaires were coded and entered into Statistical Package for Social Sciences (SPSS) version 25.0 for analysis. Descriptive statistics were used to analyse the data. Thematic content analysis was used to analyse qualitative data obtained from in-depth interviews, FGDs and observations. This method involved identifying, analysing and reporting themes within the data.

\section{Ethical consideration}

Ethical clearance to conduct the study was obtained from the Humanities and Social Sciences Research Ethics Committee of the University of KwaZulu-Natal (ethical clearance number: HSS/1819/018M).

\section{Results and discussion Socio-economic demographics}

A total of 66 fishers participated in the study. Results (Table 1) show that most of the respondents who were interviewed fall under the $26-35$ years age group (41\%), followed by the $36-45$ years age group (30\%). Eleven per cent of the fishers were below 25 years of age and the $46-55$ and $56-65$ years age groups both constituted $9 \%$ of the respondents. The fishing sector is male dominated, with $89 \%$ of the fishers being men and $11 \%$ women. The majority (85\%) of the participants were married, $8 \%$ were divorced, $6 \%$ were single and $2 \%$ were widowed. The fishing community depicts a high literacy level, with $98 \%$ of the fishers having attended formal education. Fishing households in Sanyathi fishing basin are characterised by multiple livelihood activities. Table 1 shows that $80 \%$ of the respondents are fishermen, $16 \%$ also involved in agriculture and $15 \%$ also engaged in fish drying.

\section{Challenges or stressors experienced by fishers}

Small-scale fishers are exposed to various livelihood stressors. The themes that emerged from the qualitative data analysis were categorised into two categories: (1) climate-induced challenges (challenges emanating from and aggravated by climate change) and (2) non-climate-related challenges shown in Table 2. 
TABLE 1: Demographic characteristics of respondents.

\begin{tabular}{|c|c|c|c|}
\hline \multicolumn{2}{|l|}{ Variable } & \multirow{2}{*}{$\begin{array}{c}\text { Frequency } \\
(n=66)\end{array}$} & \multirow{2}{*}{$\begin{array}{c}\% \\
10.6\end{array}$} \\
\hline Age, years & $<25$ & & \\
\hline & $26-35$ & 27 & 40.9 \\
\hline & $36-45$ & 20 & 30.3 \\
\hline & $46-55$ & 6 & 9.1 \\
\hline & $56-65$ & 6 & 9.1 \\
\hline \multirow[t]{2}{*}{ Gender } & Male & 59 & 89.4 \\
\hline & Female & 7 & 10.6 \\
\hline \multirow[t]{4}{*}{ Marital status } & Single & 4 & 6.1 \\
\hline & Married & 56 & 84.8 \\
\hline & Divorced & 5 & 7.6 \\
\hline & Widowed & 1 & 1.5 \\
\hline \multirow{4}{*}{$\begin{array}{l}\text { Respondents' } \\
\text { educational level }\end{array}$} & No formal school & 1 & 1.5 \\
\hline & Primary school & 15 & 22.7 \\
\hline & Secondary school & 46 & 69.7 \\
\hline & Tertiary school & 4 & 6.1 \\
\hline \multirow{8}{*}{$\begin{array}{l}\text { Livelihood strategies } \\
\text { (employment) }\end{array}$} & Fisherman & 53 & 80.3 \\
\hline & Labourer in fisheries & 8 & 12.1 \\
\hline & Crew leader/chief fisherman & 3 & 4.5 \\
\hline & Boat owner (renting out boats) & 4 & 6.1 \\
\hline & Fish drying & 10 & 15.2 \\
\hline & Net making or mending & 4 & 6.1 \\
\hline & Agriculture & 11 & 16.7 \\
\hline & Trading & 4 & 6.1 \\
\hline
\end{tabular}

TABLE 2: Challenged experienced by fishers in Sanyathi fishing basin. Climate-induced challenges Non-climate-related challenges

- Declining fish catches

- Destruction of infrastructure

- Water currents (tide) and wind

- Crayfish (invasive species)

- Food insecurity

- Shrinking fishing boundaries

\section{Declining fish catches}

The majority of the fishers (80\%) agreed that fish catches in their fishing zones have been declined compared to previous years. These study findings confirm Ndhlovu et al.'s (2017) and Ndebele-Murisa, Mashonjowa and Hill's (2011) research findings that fish catches of small-scale fishermen in Lake Kariba are declining. The fishers believe that the continuously declining of fish catches will negatively affect their livelihoods, incomes and food security. From the fishers' point of view, declining fish catches are not attributed to a single cause but several causes. Climate change emanated as one of the major factors causing fish catches to decline. Ndebele-Murisa et al. (2011) assert that declining fish catches in Lake Kariba is attributed to climate change. The study results are congruent with Limuwa et al.'s (2018) research findings where $89 \%$ of fishers in Lake Malawi reported that climate change is the main driver of low fish catches. In the Delta State of Nigeria, fishers believe that climate change has led to poor fish harvests (Aphunu \& Nwabeze 2012). Climate change is argued to have resulted in a decline of fish catches in Faza Island, Lamu East district of Kenya, with fish catches dropping from $800-1000 \mathrm{~kg}$ to $300-400 \mathrm{~kg}$ per trip in less than a decade (Owiti et al. 2012).

\section{Food insecurity}

Fishing is the main livelihood strategy and fish is the main source of animal protein for households in Sanyathi fishing basin. With the challenge of declining fish catches in the study area, $79 \%$ of the fishers indicated that their households are facing challenges of food insecurity. In this fishing community, fish is used for household consumption and the surplus is sold for income. Béné et al. (2016) and High Level Panel of Experts, (HLPE) (2014) assert that fisheries contribute more than one-third of the total animal protein consumed by fishing communities, especially in low-income food-deficit countries (LIFDCs). Fish provides high-quality protein and essential micronutrients to fishing populations (Fisheries 2014). Furthermore, declining fish catches will result in decreasing incomes of household fishing communities, which negatively affect the purchasing power of fishermen and jeopardise their ability to access or purchase different foods to supplement their diet. Therefore, food insecurity of fishing households can also be attributed to climate because climate variability and change directly affect fish availability. Daw et al. (2009) and Khoshnevis Yazdi and Shakouri (2010) believe that changes in climatic conditions modify the distribution and productivity of marine and freshwater resources. Changes in the geographic distribution of fish change total fish availability for catch, which potentially affects food security (Mohammed \& Uraguchi 2013).

\section{Destruction of infrastructure}

Fishers under Sanyathi fishing basin expressed that Zimbabwe Parks and Wildlife Management Authority (ZPWMA) banned the construction of permanent structures in Sanyathi fishing basin. Fishermen cannot build permanent structures for shelter because the area is protected wilderness and safari area. However, most of the fishermen were born in Sanyathi fishing basin, inheriting fishing equipment and practices from their parents and grandparents who were also fishermen in the same area. Despite the time they have resided in the area, ZPWMA rejected to declare households and communities under Sanyathi fishing basin to be permanent residents. Therefore, shelters in the fishing basin are constructed using mud and wood for the walls and the roofs are grass and wooden poles. These temporary structures are susceptible to the risk of floods and cyclones.

The occurrence of extreme weather events can result in loss of human lives as the temporary structures cannot shelter the fishermen from harsh weather events. Climate change in the tropics is characterised by unpredictable extreme weather events like floods, cyclones and heat waves. Mboya (2013) postulates that adverse weather events can destroy productive assets and public physical infrastructure.

\section{Water currents (tide) and winds}

Most of the fishers (67\%) in Sanyathi fishing basin indicated that fishing practices are frequently disrupted by unstable 
winds which fishers consider to be a driver of increasing waves or unstable water currents. Harsh winds and unstable water currents pose a great challenge to fishing activities. Binga wind or wave is a name given to one of the most devastating wind or wave in Lake Kariba by the local residents. Binga wind was identified as one of the most dangerous winds that poses risks to fishers' lives during fishing practices. Small-scale fisheries in Lake Kariba are characterised by the use of low-cost fishing equipment. The fishermen use small unmotorised boats which are at risk of capsizing under harsh winds and tides in the lake. Therefore, harsh winds and tide reduce the fishing days of the fishermen. Reduced fishing days negatively impact total fish catches, which affect the household income and food security. Ndhlovu et al. (2017) postulated that fishers may sometimes go for periods of up to 3 days without fishing because of winds and storms. Ndhlovu et al. (2017) also stated that winds and unstable water currents are also a challenge to fisheries in the Benguela Current Large Marine Ecosystem. Increasing strong winds were also reported by fishermen in Ngobe villages, Cayo Cayo de Agua and Tigre in Panama, who reported that tides are a great challenge to their fishing activities and result in less fishing days (Basu, 2016). Furthermore, a study conducted by Muktha et al. (2016) on the fishermen's perceptions of climate change concluded that fishermen in Andhra Pradesh reported that wind intensity is the most critical change impacting fisheries as wind velocities would impact the water currents, navigation and fishing effort.

\section{Crayfish (invasive predator species)}

Small-scale fishermen of Sanyathi fishing basin use gill nets to catch fish. The fishermen reported that currently there is a growing concern about crayfish, which is a predator fish that feeds on other fish, which directly affects their fish catches. Helfrich and DiStefano (2005) postulated that crayfish are both predator and prey fish that live in freshwater streams, ponds, lakes, swamps and marshes around the world. Fishermen in Sanyathi fishing basin trap fish, usually tilapia and tiger fish species. The fish are trapped using nets overnight, and the more they stay trapped the more vulnerable they are to be eaten by crayfish from the nets. When the fishermen pull the nets, after a whilst some of the fish that were caught by the nets will be eaten and some fish parts remain on the nets. The ecologist from LKFRI confirmed that there is an increase in the abundance of crayfish in Lake Kariba. Rahel and Olden (2008) stated that:

[C]limate change may provide suitable thermal conditions to allow non-native warm water fish species to thrive in lakes and such species may prey on or compete for food resources with native fishes, leading to the decline or loss of native fish populations. (p. 522)

\section{Wildlife}

Zimbabwe Parks and Wildlife Management Authority declared Kariba area to be a protected wildlife habitat. Hence, fishing communities that fall under Kariba district administrative area share space and resources with wildlife. Fishermen in Sanyathi fishing basin pointed that dwindling natural resources in their fishing zone has resulted in an increased competition of resources between humans and wild animals. Wildlife attacks are increasing in the fishing zone. Fishermen are vulnerable to crocodile and hippopotamus attacks, with an estimated six lives lost to hippopotamus attacks from 2017 up to the study data collection period (early 2019). Crocodile attacks have caused several mortalities and injuries to fishermen and some community members. Community members rely on water from Lake Kariba for household consumption. Household members use buckets to fetch water from the lake banks, which make them more susceptible to crocodile attacks. During the study period, one community member lost her hand to a crocodile attack as she was fetching water for household use. Ndhlovu et al. (2017) stated that more than $95 \%$ of fishers in Lake Kariba experienced threats from wildlife, mainly crocodiles and hippopotamus, during their fishing operations. Mozumder et al. (2018) stated that SSFs in Sundarbans Mangrove Forest in Bangladesh experience attacks from wild tigers.

\section{Lack of access to information and early warning systems}

Sanyathi fishing basin is a marginalised and isolated community. It has no access to electricity and proper transportation methods. It is important for fishers to know about the prevailing and future weather predictions in advance before getting into the lake to undertake their fishing activities. Kariba region has a local radio station (Nyaminyami radio station) which is responsible for sharing information that are of interest particularly to the residents of Kariba. The information shared on Nyaminyami radio station encompasses weather information that is essential to fishermen. However, because of the lack of electricity in Sanyathi fishing basin, fishermen have no access to weather information. Lack of information on predicted weather events leaves fishermen in Sanyathi fishing basin vulnerable to death threats inclined to extreme weather events. For example, Lake Kariba experiences a life-threatening current or wave in the summer season called the Binga wave or current, which fishermen cannot predict when it will occur. Practically, fishermen use their own judgements to predict weather patterns and sometimes severe weather events occur whilst they are unaware.

\section{Fishing equipment}

The majority of the fishers (73\%) indicated that lack of access to fishing equipment is one of the major challenges impeding their fishing practices. Fishermen in Sanyathi fishing basin are gillnet fishermen. Gillnet fishing method is the widely used method by SSFs in Sanyathi fishing basin. Mendonca and Pereira (2014) argue that gillnet fishing method is a widely used fishing method used by both industrial fisheries and SSFs. Gillnet fishing entails the use of nets to catch fish. The fishermen use small boats and nets during their fishing 
practices. Fishermen in the study stated that in Zimbabwe there are no fishing nets producers; hence, the fishermen purchase and smuggle in fishing nets from Zambia and Mozambique. It is costly for fishermen to purchase nets from neighbouring countries. Purchasing of equipment from neighbouring countries causes financial constraints (acquiring forex is very expensive in a country hard hit by a cash crisis and depreciating currency), and the time that could be used for fishing activities is wasted during the fishing nets procurement process.

\section{Lake co-management}

Another widely held view (opined by $58 \%$ of respondents) was that the main two authorities (LKFRI and ZPWMA) who co-manage fishing activities in Lake Kariba work in silos. Fishers believe that there is no coordination between the two authorities who oversee the fishing activities. Lake Kariba Fisheries Research Institute is a department under ZPWMA that focuses on regulating fishing practices and licensing of both commercial and SSFs. On the contrary, ZPWMA regulates all activities done in the protected wilderness and safari areas including fishing activities. The fishermen reported that the fishing regulations brought forward to them by LKFRI are different from the fishing regulations brought forward by ZPWMA despite the two organisations being under the same management. For example, one respondent from FGD 1 noted that:

'LKFRI provides maps with defined fishing boundaries where the fishermen are supposed to carry out their fishing activities. However, these maps are not shared with ZPWMA lake patrol officers and in such cases, fishermen face arrest and confiscation of fishing equipment for fishing in unauthorized areas which results in disrupted fishing schedules.' (male, fishermen, literate)

In Lake Kariba, gill net fishers are allowed to cast their fishing nets after 18:00 in the evening and are supposed to remove their fishing nets before 06:00 in the morning, and failure to do so subjects them to fines. The fishermen stated that because of unpredictable and increasingly fluctuating weather conditions, sometimes they will not be able to get into the lake and remove their nets before 6:00 as required by the lake authority, and have to wait for the wind and water current to calm in order to safely remove the fishing nets. However, if ZPWMA lake patrol officers find the nets in the water after 6:00, the fishermen are prone to fines, possible arrest and seizure of the fishing equipment.

\section{Fishing boundaries}

Another $61 \%$ of the fishers reported that decreasing fishing boundaries is also a challenge experienced by fishermen in Lake Kariba. Shrinking fishing boundaries can be attributed to both climate change and lake management factors. Lake Kariba Fisheries Research Institute regulates and monitors the fishing practices undertaken on the Zimbabwean side of Lake Kariba. It determines the fishing boundaries for different communities as a way of regulating detrimental fishing practices and to conserve the lake species. Fishers indicated that the fishing boundaries where they can fish are small and are continuing to shrink. The fishermen are of the notion that LKFRI is reducing the sizes of the fishing grounds which has resulted in increasing competition on limited aquatic resources.

On the contrary, fishermen also believe that climate change contributes to the problem of shrinking fishing boundaries. One of the respondents from FGD 2 said:

'Our fishing boundaries are continuously decreasing because of climate change. Climate change has resulted in decreasing rainfall in our area which is causing the dam water level to drop, thereby negatively affecting our fishing boundaries.' (male, fishermen)

Barange and Perry (2009) stated that in the past few decades several lakes worldwide have decreased in size because of declining precipitation and increasing human water use (e.g. Lake Chad). Decreasing of the lake size directly affects the fishing boundaries of fishers by shrinking the fishing grounds. Records show that freshwater lakes have altered their shapes and distributions and have disappeared entirely with the processes related to climate change (Cochrane et al. 2009).

\section{Conclusion}

The objective of this study was to assess challenges that affect livelihoods of fishing-dependent households of Sanyathi fishing basin in Lake Kariba. The study revealed that fishing practices are exposed to multiple, simultaneous and interconnected environmental, social, political and economic pressures. In many instances, it is quite difficult to determine the main causes of the depletion of fish stocks. Climate change and variability exacerbate the already existing socioeconomic challenges experienced by fishers because of the SSFs' lack of alternative livelihood strategies. Therefore, it is essential for the development agencies to understand both climate-induced and non-climate-related challenges experienced by small-scale fishermen at the community level for the formulation of effective policies that could address the given challenges.

\section{Acknowledgement}

The authors thank the small-scale fishers of Lake Kariba for particiapting in the study, as well as the Lake Kariba Fisheries Research Institute for their assiatance in accessing small-scale fishers.

\section{Competing interests}

The authors have declared that no competing interest exists.

\section{Authors' contributions}

R.T.M. designed the study, collected and analysed the data and wrote the article. D.N. and P.M. supervised the writing process. 


\section{Funding information}

This research received no specific grant from any funding agency in the public, commercial or not-for-profit sectors.

\section{Data availability statement}

Data sharing is not applicable to this article as no new data were created or analysed in this study.

\section{Disclaimer}

The views and opinions expressed in this article are those of the authors and do not necessarily reflect the official policy or position of any affiliated agency of the authors.

\section{References}

Aphunu, A. \& Nwabeze, G., 2012, 'Fish farmers' perception of climate change impact on fish production in Delta State, Nigeria', Journal of Agricultural Extension 16(2), 1-13. https://doi.org/10.4314/jae.v16i2.1

Barange, M., Bahri, T., Beveridge, M., Cochrane, K., Funge-Smith, S. \& Poulain, F. 2018, Impacts of climate change on fisheries and aquaculture: Synthesis of currrent knowledge, adaptation and mitigation options, FAO, Rome.

Barange, M. \& Perry, R.I., 2009, 'Physical and ecological impacts of climate change relevant to marine and inland capture fisheries and aquaculture', in K. Cochrane, C. De Young, D. Soto \& T. Bahri (eds.), Climate change implications for fisheries and aquaculture: Overview of current scientific knowledge, pp. 7-106, FAO, Rome.

Basu, I., 2016, Small-scale fishing in Central American indigenous people: Governance, tenure and sustainable management of marine resources, International Collective in Support of Fishworkers, Chennai.

Basurto, X., Virdin, J., Smith, H. \& Juskus, R., 2017, Strengthening governance of smallscale fisheries: An initial assessment of theory and practice, Oak Foundation, viewed 23 May 2019, from http://www.oakfnd.org/environment.

Béné, C., Arthur, R., Norbury, H., Allison, E.H., Beveridge, M., Bush, S. et al., 2016 , 'Contribution of fisheries and aquaculture to food security and poverty reduction: Assessing the current evidence', World Development 79, 177-196. https://doi. org/10.1016/j.worlddev.2015.11.007

Benkenstein, A., 2013, Small-scale fisheries in a modernising economy: Opportunities and challenges in Mozambique, viewed 25 May 2019, from https://www.files. ethz.ch/isn/169459/saia_rpt_13_\%20benkenstein_20130911.pdf.

Blythe, J., Murray, G. \& Flaherty, M., 2014, 'Strengthening threatened communities through adaptation: Insights from coastal Mozambique', Ecology and Society 19(2), 6. https://doi.org/10.5751/ES-06408-190206

Cawthorn, R.G., 2011, 'Changing fish stocks in Lake Kariba: Climatic or human-induced impact?', Transactions of the Royal Society of South Africa 66(3), 219-220. https:// doi.org/10.1080/0035919X.2011.632446

Cochrane, K., De Young, C., Soto, D. \& Bahri, T., 2009, 'Climate change implications for fisheries and aquaculture', FAO Fisheries and Aquaculture Technical Paper, No. 530, p. 212, FAO, Rome.

Daw, T., Adger, W.N., Brown, K. \& Badjeck, M-C., 2009, 'Climate change and capture fisheries: Potential impacts, adaptation and mitigation', in $K$. Cochrane, C. de Young, D. Soto \& T. Bahri (eds), Climate change implications for fisheries and aquaculture: Overview of current scientific knowledge, pp.107-150, FAO Fisheries and Aquaculture Technical Paper. No. 530, FAO, Rome.

FAO, 2019, Fishery and Aquaculture Country Profile: The Republic of Zimbabwe [online], FAO, viewed 20 March 2019, from https://www.fao.org/fishery/facp/ ZWE/en.
Frawley, T., Finkbeiner, E. \& Crowder, L., 2019, 'Environmental and institutional degradation in the globalized economy: Lessons from small-scale fisheries in the Gulf of California', Ecology and Society 24(1), 7. https://doi.org/10.5751/ESGulf of Californ

Gammage, L.C., Jarre, A. \& Mather, C., 2017, 'A case study from the southern Cape linefishery 1: The difficulty of fishing in a changing world', South African Journal of Science 113(5/6), 1-8. https://doi.org/10.17159/sajs.2017/20160252

Helfrich, L.A. \& DiStefano, R.J., 2005, 'Sustaining America's aquatic biodiversity', in L.A. Helfrich, R.J. Neves \& J. Parkhurst (eds.), Crayfish biodiversity and conservation, pp. 420-523, Virginia Cooperative Extension - Virginia Tech, Blacksburg, VA.

High Level Panel of Experts, 2014, 'Aquaculture for food security and nutrition', report by the High Level Panel of Experts on Food Security and Nutrition of the Committee on World Food Security, Rome.

Hossain, M., Islam, M., Sakai, T. \& Ishida, M., 2008, 'Impact of tropical cyclones on rural infrastructures in Bangladesh', Agricultural Engineering International: CIGR Journal 10(2), 1-13.

Khoshnevis Yazdi, S. \& Shakouri, B., 2010, 'The effects of climate change on aquaculture', International Journal of Environmental Science and Development 1(5), 378. https://doi.org/10.7763/IJESD.2010.V1.73

Kotir, J.H., 2011, 'Climate change and variability in sub-Saharan Africa: A review of current and future trends and impacts on agriculture and food security', Environment, Development and Sustainability 13(3), 587-605. https://doi. org/10.1007/s10668-010-9278-0

Limuwa, M., Sitaula, B., Njaya, F. \& Storebakken, T., 2018, 'Evaluation of small-scale fishers' perceptions on climate change and their coping strategies: Insights from Lake Malawi', Climate 6(34), 1-23. https://doi.org/10.3390/cli6020034

Mboya, O., 2013, 'Effects of weather and climate variability on fishing activities and fishers adaptive capacity in mbita division-homa bay county', PhD dissertation, Kenyatta University, Nairobi.

Mendonca, J.T. \& Pereira, A.L., 2014, 'Management of gillnet fisheries in the south coast of the state of São Paulo, Brazil', Anais da Academia Brasileira de Ciências 86(3), 1227-1237. https://doi.org/10.1590/0001-3765201420130139

Mohammed, E.Y. \& Uraguchi, Z.B., 2013, 'Impacts of climate change on fisheries: Implications for food security in sub-Saharan Africa', in M.A. Hanjra (ed.), Globa food security, pp. 114-135, Nova Science Publishers, Inc., Hauppauge, NY.

Mozumder, M.M.H., Shamsuzzaman, M.M., Rashed-Un-Nabi, M. \& Karim, E., 2018, 'Social-ecological dynamics of the small scale fisheries in Sundarban Mangrove forest, Bangladesh', Aquaculture and Fisheries 3(1), 38-49. https://doi. org/10.1016/j.aaf.2017.12.002

Muktha, M., Ghosh, S., Satish Kumar, M., Rao, M., Uma Mahesh, V. \& Zacharia, P. 2016, 'Fishermen's perception of climate change - A study from Andhra Pradesh', Indian Journal of Fisheries 61(3), 110-119.

Ndebele-Murisa, M.R., Mashonjowa, E. \& Hill, T., 2011, 'The implications of a changing climate on the Kapenta fish stocks of Lake Kariba, Zimbabwe', Transactions of the Royal Society of South Africa 66(2), 105-119. https://doi.org/10.1080/003591 Royal Society of

Ndhlovu, N., Saito, O., Djalante, R. \& Yagi, N., 2017, 'Assessing the sensitivity of smallscale fishery groups to climate change in Lake Kariba, Zimbabwe', Sustainability 9(12), 2209. https://doi.org/10.3390/su9122209

Owiti, H., Waiyaki, E., Angwenyi, R. \& Muriuki, T., 2012, An assessment of perceived socioeconomic impacts of climate change on the community of Faza Island, Lamu East District, Kenya, viewed 23 May 2019, from https://www.oceandocs.org/ bitstream/handle/1834/6959/ktf0331. pdf?sequence=2.

Rahel, F.J. \& Olden, J.D., 2008, 'Assessing the effects of climate change on aquatic invasive species', Conservation Biology 22(3), 521-533. https://doi.org/10.1111/ j.1523-1739.2008.00950.x

Rockefeller Foundation, 2013, Securing the livelihoods and nutritional needs of fish dependent communities, viewed 03 October 2018, from https://assets. rockefellerfoundation.org/app/uploads/20150401225417/Securing-theLivelihoods-and-Nutritional-Needs-of-Fish-Dependent-Communities.pdf.

Food and Agriculture Organisation, 2016, Technical and socio-economic characteristics of small-scale coastal fishing communities, and opportunities for poverty alleviation and empowerment, by Uwe Tietze, FAO Fisheries and Aquaculture Circular No. 1111. Rome, Italy.

World-Bank, 2013, 'Fish to 2030: Prospects for fisheries and aquaculture', Agriculture and Environmental Services Discussion Paper, No. 3, World Bank Group, Washington, DC. 